\title{
PENGUKURAN EFEKTIVITAS MEDIA PROMOSI DENGAN PENDEKATAN MODEL EPIC TERHADAP KEPUTUSAN PEMBELIAN KONSUMEN PADA TOKO BANGUNAN RADIN TIMUR, DI JEBRES KOTA SURAKARTA
}

\author{
Kevin Rahman Hayadi', \\ Manajemen, Fakultas Ekonomi dan Bisnis Universitas Tunas Pembangunan Surakarta \\ Laksono Sumarto ${ }^{2}$, \\ Manajemen, Fakultas Ekonomi dan Bisnis Universitas Tunas Pembangunan Surakarta \\ Suyamto ${ }^{3}$, \\ Manajemen, Fakultas Ekonomi dan Bisnis Universitas Tunas Pembangunan Surakarta
}

\begin{tabular}{l} 
Info Artikel \\
\hline Kata kunci: \\
Model Epic, Keputusan \\
Pembelian, Regresi \\
Linier Berganda \\
Alamat korespondensi : \\
Kevin Rahman Hayadi \\
E-mail: \\
(kevrahmanhayadi@gma \\
il.com) \\
\hline
\end{tabular}

Kata kunci:

Model Epic, Keputusan

Pembelian, Regresi

Berganda

(kevrahmanhayadi@gma

\begin{abstract}
Abstrak
Tujuan dari penelitian adalah (1) Untuk mengetahuui pengaruh secara individual (parsial) empati, persuasi, dampak, dan komunikasi terhadap keputusan pembelian konsumen pada Toko Bangunan Radin Timur, Jebres Surakarta. (2) Untuk mengetahu faktor yang paling dominan pengaruhnya terhadap keputusan pemelian konsumen pada Toko Bangunan Radin Timur, Jebres Surakarta.(3) Untuk mengetahui interaksi pengaruh secara simultan EPIC terhadap keputusan pemelian konsumen pada Toko Bangunan Radin Timur, Jebres Surakarta. Peneltian ini dilakukan di Toko Bangunan Radin Timur, yang berralamat di Jalan. Ir. Sutami No.59B, Pucangsawit, Kecamatan Jebres kota Surakarta. Dengan menggunakan sapel sebanya 38 pelanggan aktif.

Hasil penelitian ditemukan bahwa secara parsial dan simultan empati, persuasi, dampak, dan komunikasi terhadap keputusan pembelian konsumen. Variabel Empati paling domain pengaruhnya terhadap keputusan pembelian. Sumbangan pengaruh dari variabel empati, persuasi, dampak, dan komunikasi, terhadap Keputusan Pembelian sebesar 89,20\%, sedangkan sisanya yaitu $10.80 \%$ berasal dari pengaruh faktor-faktor lain di luar penelitian ini.
\end{abstract}

\section{PENDAHULUAN}

Toko Bangunan Radin Timur adalah salah satu toko yang berlokasi di Jalan. Ir. Sutami No.59B, Pucangsawit, Kecamatan Jebres. Kecamatan Jebres, merupakan daerah berkembang dan potensial di Kota Surakarta. Daerah tersebut masih terdapat area lahan tanah kosong dan ladang sawah, dengan latar belakang masyarakat sekitar mayoritas bekerja sebagai pekerja kasar, petani dan pegawai swasta. Seiring berjalannya waktu dan peningkatan jumlah penduduk, maka semakin hari semakin meningkat pertumbuhan kebutuhan rumah akan mengalami peningkatan yang pesat. Hal ini tentu menjadi suatu permasalahan pokok mendasar di kalangan masyarakat, untuk membangun rumah atau berusaha memperbaiki kondisi permukimannya relatif besar. Dampak dari meningkatnya pembangunan, maka permintaan bahan bangunan akan meningkat pula, pelaku bisnis bahan bangunan berusaha bekerja secara efektif dan professional.

Di tengah pertumbuhan ekonomi Indonesia yang menurun seiring dengan pandemi COVID19, ini bukanlah saat yang tepat untuk melakukan "trial and error" terkait strategi pemasaran yang akan dilakukan oleh Toko Bangunan Radin Timur. Menjual selama pandemi Covid 19 merupakan 
aktivitas yang mudah namun sulit dilakukan. Selain itu, karena masalah pesaing yang telah memulai sebelum Toko Bangunan Radin Timur melakukannya. Bahkan, beberapa di antaranya merupakan kompetitor muda yang lebih sukses dalam menggunakan promosi dengan memadukan media elektronik dan media non elektronik.

Kedua model promosi ini mendapat perhatian tajam karena aspek informasi merupakan bagian penting dari bisnis, aktivitas periklanan yang efektif dipandang mampu mempengaruhi kecenderungan konsumsi di masyarakat. Iklan yang efektif akan mengubah pengetahuan masyarakat tentang ketersediaan dan karakteristik suatu produk, elastisitas permintaan produk akan sangat dipengaruhi oleh kegiatan promosi / periklanan. Berbagai hasil penelitian menunjukkan bahwa anggaran promosi berpengaruh positif terhadap penjualan dan pangsa pasar, sedangkan peningkatan anggaran promosi pesaing berpengaruh negatif terhadap tingkat penjualan dan pangsa pasar para pesaingnya (Durianto et al., 2017). Dampak periklanan bervariasi tergantung pada keefektifannya, sehingga anggaran periklanan yang lebih besar tidak selalu dapat mengubah penjualan dan pangsa pasar ke tingkat yang lebih besar.

Efektivitas periklanan memperoleh perhatian yang serius, strategi dan program yang handal diperlukan untuk mencapai dampak promosi yang diinginkan, terlebih lagi diperlukan pula teknik pengukuran untuk memantau efektivitas promosi baik secara kuantitatif maupun kualitatif. Berdasarkan keterangan di atas maka dapat diketahui bahwa strategi promosi yang tepat sangatlah diperlukan perusahaan agar kegiatan perusahaan dapat berjalan dengan lancar, oleh karena itu penulis tertarik untuk melakukan penelitian terhadap strategi promosi dalam hal ini iklan yang sudah dilakukan oleh toko Bangunan Radin Timur di Jebres, yang diharapkan akan mampu mengatasi kurang optimalnya periklanan yang dilakukan.

\section{TINJAUAN PUSTAKA, KERANGKA PEMIKIRAN DAN HIPOTESIS}

\section{a. Tinjauan Pustaka}

1. Promosi

\section{a. Fungsi Promosi}

Promosi merupakan arus informasi atau persuasi satu-arah yang dibuat untuk mengarahkan seseorang atau organisasi kepada tindakan yang menciptakan pertukaran dalam pemasaran (Swastha, 2013: 237). Dengan melalui berbagai macam kegiatan informasi, hakekatnya adalah untuk menciptakan terjadinya pertukaran atau pembelian. Baik dengan periklanan, promosi, penjualan, personal selling, publisitas, diharapkan akan terciptanya pertukaran atau pembelian, yang bagi perusahaan ditandai dengan kegiatan penjualan produknya.

Tujuan promosi penjualan bersumber pada tujuan komunikasi pemasaran. Tujuan ini dijabarkan dari tujuan pemasaran yang lebih mendasar, yang dirancang untuk produk tertentu. jenis pasar target. Menurut Philip Kotler, tujuan khusus yang ditentukan untuk promosi penjualan akan beraneka ragam, tergantung dari konsumen, pengecer, dan wiraniaga (Kotler, 2008: 297).

Bagi konsumen, tujuan tersebut mencakup usaha mendorong konsumen antara lain untuk lebih banyak menggunakan produk, untuk membeli produk dalam jumlah yang lebih besar, mencoba merk yang sdipromosikan dan untuk menarik pembeli merk lain yang bersaing dengan merk produk yang sedang dipromosikan.

Bagi pengecer, tujuan promosi adalah membujuk pengecer untuk menjual barang produk baru dan menimbun lebih banyak persedian barang, menggiatkan pembelian ketika sedang tidak musim, membujuk agar menimbun barang-barang yang dipromosikan, mengimbangi promosi para pesaing, membuat para pengecer agar setia terhadap merk yang dipromosikan, dam memperoleh jalur pengeceran baru.

Bagi wiraniaga, tujuannya adalah berusaha untuk memberi dukungan atas produk atau model baru, untuk merangsang mereka mencari pelanggan-pelanggan, baru dan mendorong penjualan di musim sepi.

Dari hal tersebut, dapat diketahui bahwa fungsi promosi adalah :

1) Menyampaikan informasi

2) Membujuk/mempengaruhi 
3) Menciptakan kesan (image)

4) Memuaskan keinginan

5) Sebagai alat komunikasi

\section{b.Tujuan Promosi}

Di samping telah diketahui fungsi promosi, perlu juga diketahui seputar tujuan promosi. Dalam praktek promosi dapat mendasarkan pada tujuan-tujuan :

1) Merubah tingkah laku dan pendapat, memperkuat tingkah laku yang ada.

2) Memberitahu pasar yang dituju tentang penawaran perusahaan.

3) Membujuk kearah pembelian

4) Mempertahankan merk produk di hati masyarakat

\section{c. Manfaat dan Kelemahan Kegiatan Promosi}

Untuk dapat memilih salah satu atau beberapa jenis kegiatan, perlu diketahui tentang manfaat dan kelemahan ketiga jenis kegiatan promosi di atas.

1) Manfaat Kegiatan Promosi

a) Promosi Penjualan

(1)

b) Periklanan

c) Personal Selling

2) Kelemahan Kegiatan Promosi

a) Promosi penjualan

(1) Daya jangkau promosi penjualan tidak seluas promosi yang dilakukan dengan iklan.

(2) Efektivitas jangka panjang promosi penjualan lemah.

(3) Untuk memilih/menentukan alternatif pada jenis promosi penjualan, membutuhkan riset yang lebih banyak.

b) Periklanan

(1) Kelemahan kegiatan promosi Informasi hanya diketahui oleh masyarakat yang melihat atau mendengar iklan yang bersangkutan. Ada kalanya calon konsumen tidak melihat dan mendengar iklan yang menawarkan produk yang diperlukan oleh konsumen pada saat produk itu diiklankan.

(2) Iklan mudah diabaikan oleh masyarakat atau konsumen.

c) Personal selling

(1) Untuk dapat menjangkau calon pembeli yang banyak diperlukan tenaga, waktu dan biaya yang banyak.

(2) Untuk meningkatkan jumlah dan kemampuan tenaga penjualan, memerlukan biaya yang besar.

Mengingat adanya manfaat dan kelemahan pada masing-masing jenis kegiatan promosi, suatu perusahaan tidak harus hanya melaksanakan satu jenis kegiatan promosi dan menyampaikan jenis lain. Tetapi perlu mempertimbangkan pelaksanaan beberapa jenis kegiatan promosi, agar saling mendukung, dalam arti dapat menambah manfaat dan mengurangi kelemahannya.

\section{d. Pengaruh Biaya Promosi Terhadap Volume Penjualan}

Salah satu masalah paling sulit adalah mengukur berapa besarnya biaya promosi. Ada empat metode umum yang digunakan untuk meningkatkan anggaran total promosi atau komponen lain seperti iklan.

1) Metode Semampunya.

2) Metode Persentase Penjualan.

3) Metode Sejajar dengan Pesaing

4) Metode Tugas dan Sasaran (Kotler, 2008: 255).

Adapun penjelasan dari metode-metode di atas yaitu :

\section{Iklan}


a. Pengertian Iklan

Pengertian iklan secara komprehensif adalah "semua bentuk aktivitas untuk menghadirkan dan mempromosikan ide, barang, atau jasa secara nonpersonal yang dibayar oleh sponsor tertentu. Jhon, (2013) menyatakan bahwa periklanan adalah segala bentuk penyajian non personal, promosi dan ide, barang ataupun jasa oleh sponsor tertentu yang memerlukan pembayaran. Sedangkan menurut Durianto et al., (2017) periklanan merupakan suatu proses komunikasi yang bertujuan untuk membujuk atau menggiring orang untuk mengambil tindakan yang menguntungkan bagi pihak pembuat iklan.

Periklanan merupakan satu dari empat alat penting yang digunakan oleh perusahaan untuk memperlancar komunikasi persuasif terhadap pembelian dan masyarakat yang ditargetkan. Kemudian juga definisi iklan dan periklanan yang dipopulerkan oleh AMA (American Marketing Association) adalah iklan sebagai semua bentuk bayaran untuk mengimplementasikan dan mempromosikan ide, barang atau jasa secara non personal oleh sponsor yang jelas, sedangkan periklanan adalah seluruh proses yang meliputi penyiapan, perencanaan, pelaksanaan dan pengawasan iklan (Tjiptono, 2014: 229). Iklan ini juga merupakan salah satu kegiatan yang dilakukan oleh Toko Bangunan Radin Timur dalam rangka memasarkan produk-produknya. Adapun defenisi dari Iklan menurut Aaker, et al., (2011) adalah "Penyampaian informasi dari penjual kepada pembeli untuk mempengaruhi sikap dan tingkah laku". Iklan merupakan bagian dari komunikasi yang terdiri dari berbagai kegiatan untuk memberikan informasi dari komunikasi kepada pasar sasaran akan adanya suatu produk baik berupa barang, jasa dan ide. Berhasil tidaknya Iklan yang dilakukan tergantung dari media mana yang digunakan untuk mencapai sasaran, oleh karenanya masalah pemilihan media iklan tidak hanya didasarkan pada perkiraan saja, melainkan harus diperhatikan sifat-sifat iklan dan faktor-faktor lain yang mempengaruhi kegiatan iklan yang dilakukan. Menurut Tjiptono (2014: 240) faktor-faktor yang perlu diperhatikan dalam memilih media iklan adalah :

1) Dana yang digunakan untuk iklan

Jumlah dana tersedia merupakan faktoir penting yang mempengaruhi bauran iklan, perusahaan yang memiliki dana yang lebih besar kegiatan iklannya akan lebih efektif dibanding dengan perusahaan yang memiliki dana yang terbatas.

\section{2) Sifat Pasar}

Beberapa sifat pasar yang mempengaruhi sifat bauran ini meliputi : luas pasar secara geografis, konsentrasi pasar, macam pembeli.

3) Jenis Produk

Strategi iklan yang dilakukan oleh perusahaan dipengaruhi juga oleh jenis produksinya, apakah barang konsumsi atau barang industri.

4) Tahap-Tahap Dalam Siklus Kehidupan Barang

Strategi yang diambil untuk mengiklankan barang dipengaruhi oleh tahap-tahap siklus kehidupan barang yaitu tahap perkenalan, pertumbuhan, kedewasaan dan tahap kejenuhan.

b. Faktor-faktor Yang Perlu Dipertimbangkan dalam beriklan

Kriteria yang dipakai untuk menentukan faktor kunci adalah apakah informasi tersebut akan mempengaruhi pilihan iklan yang digunakan.

1) Pemilihan waktu

Ini selalu penting dan dapat dibagi menjadi beberapa segi :

a) Kapan konsep pemasaran harus siap

b) Kapan iklan tersebut akan berjalan

c) Berapa lama iklan tersebut akan berjalan

Pemilihan waktu pada setiap tahap akan sangat mempengaruhi apa yang dapat dan tidak dapat tercapai.

2) Pasar sasaran 
Pasar sasaran menentukan ciri kelompok yang dituju : umur, lokasi, kelas sosial, jenis kelamin, dan frekuensi pembelian. Untuk pasar perusahaan ini akan membedakan menurut besarnya perusahaan dan jenis usahanya.

3) Perubahan-perubahan dalam pasar

Adalah menentukan hal-hal penting dari apa yang sedang terjadi dalam pasar, apakah pasar membaik atau memburuk, apa yang sedang dilakukan para pesaing, apakah dampak musiman dan lain-lain. Umumnya informasi ini tersedia banyak sekali dan karenanya kita harus selektif.

4) Nilai produk atau jasa

Bagaimana atau apa yang dimiliki oleh produk atau jasa yang ditawarkan apakah rasanya sangat menyenangkan atau kasar.

5) Pengalaman masa lalu

Hindari pemborosan waktu dengan tidak menggunakan yang dulu ternyata gagal, gagasan yang dibuang atau bonus yang dapat diterima secara etis.

c. Efektifitas Periklanan

1) Efektifitas merupakan suatu pengukuran dalam arti tercapainya tujuan yang telah ditentukan sebelumnya, maka efektifitas dapat didefinisikan dengan melakukan pekerjaan yang benar. (Drucker dan Fansusu, 2016: 14)

2) Menurut Rangkuty (2017:136) efektifitas iklan adalah pengukuran iklan dalam arti tercapainya sasaran yang telah ditentukan sebelumnya.

d. Efektifitas Iklan diukur dengan Metode EPIC Model

Efektivitas iklan dapat diukur dengan menggunakan EPIC model, Durianto et al., (2017). EPIC model yang dikembangkan oleh AC Nielsen, salah satu perusahaan peneliti pemasaran terkemuka di dunia, EPIC Model dan mencakup empat dimensi kritis yaitu empati, persuasi, dampak dan komunikasi (Empathy, Persuasion, Impact and communications - EPIC) berikut akan dipaparkan dimensi - dimensi dalam EPIC model.

1) Dimensi Empati

Dimensi empati memberikan informasi yang berharga tentang daya tarik suatu merek. Empati merupakan keadaan mental yang membuat seseorang mengidentifikasikan dirinya atau merasa dirinya pada keadaan perasaan atau fikiran yang sama dengan orang atau kelompok lain, Kamus Besar Bahasa Indonesia, (2016: 228). Empati melibatkan afeksi dan kognisi konsumen, menurut Peter dan Olson (2016), afeksi dan kognisi mengacu pada dua tipe tanggapan internal psikologis yang dimiliki konsumen terhadap rangsangan lingkungan dan kejadian yang berlangsung. Dalam bahasa yang lebih sederhana, afeksi melibatkan perasaan, sementara kognisi melibatkan pemikiran, variasi tanggapan afektif dapat berupa penilaian positif, negatif, menyenangkan atau tidak menyenangkan, dan konsumen dapat merasakan empat jenis tanggapan afektif yaitu emosi, perasaan khusus, suasana hati dan evaluasi yang berbeda dalam tingkat intensitas dan daya improvisasinya.

2) Dimensi Persuasi

Dimensi persuasi menginformasikan apa yang dapat diberikan suatu iklan untuk peningkatan atau penguatan karakter suatu merek, sehingga pemasang iklan memperoleh pemahaman tentang dampak iklan terhadap keinginan konsumen untuk membeli serta memperoleh kemampuan suatu iklan dalam mengembangkan daya tarik suatu merek. Persuasi (persuasion) adalah perubahan kepercayaan, sikap, dan keinginan berperilaku yang disebabkan satu komunikasi promosi. Komunikasi promosi, seperti periklanan, yang dapat mempengaruhi konsumen dapat menggunakan dua proses kognitif, yaitu: "jalur sentral" dan "Jalur periferal" menuju persuasi. Proses persuasi yang akan dipakai ditentukan dengan tingkat keterlibatan konsumen dalam pesan produk (Peter dan Olson, 2016).

Jalur sentral menuju persuasi (central route persuasion) cenderung muncul ketika tingkat keterlibatan konsumen meningkat. Pada jalur sentral, konsumen "memfokuskan diri pada pesan produk" dalam iklan. Konsumen menerjemahkan pesan produk dalam iklan tersebut, lalu membentuk kepercayaan tentang ciri-ciri dan 
konsekuensi produk, serta mengintegrasikan makna tersebut untuk membentuk sikap dan keinginan. Jalur periferal menuju persuasi (peripheral route persuasion) cenderung muncul ketika tingkat keterlibatan konsumen lebih rendah. Dalam jalur periferal, konsumen tidak memfokuskan diri pada pesan produk dalam sebuah iklan tetapi pada perangsang "periferal", seperti selebriti atau musik yang popular dan menarik.

3) Dimensi Impact

Dimensi Impact menunjukkan, apakah suatu merek dapat terlihat menonjol dibandingkan merek lain pada kategori yang serupa dan apakah suatu iklan mampu melibatkan konsumen dalam pesan yang di sampaikan. Dampak (impact) yang diinginkan dari hasil iklan adalah jumlah pengetahuan produk (product knowledge) yang dicapai konsumen melalui tingkat keterlibatan (involvement) konsumen dengan produk dan atau proses pemilihan. Konsumen memiliki tingkat pengetahuan produk (levels of product knowledge) yang berbeda-beda, yang dapat digunakan untuk menerjemahkan informasi baru dan membuat pilihan pembelian. Konsumen dapat memiliki empat tingkat pengetahuan produk, yaitu : kelas produk, bentuk produk, merek, dan model.

Selain itu konsumen juga dapat memiliki tiga jenis pengetahuan produk, yaitu pengetahuan tentang ciri atau karakter produk, konsekuensi atau manfaat positif menggunakan produk, dan nilai yang akan dipuaskan atau dicapai suatu produk. Keterlibataan (involvement) mengacu pada persepsi konsumen tentang pentingnya atau relevansi personal suatu objek, kejadian, atau aktifitas. Konsumen yang melihat bahwa suatu produk memiliki konsekuensi yang relevan secara pribadi, maka konsumen dikatakan terlibat dengan produk tersebut dan memiliki hubungan dengan produk tersebut. Konsekuensi dengan suatu produk atau suatu merek memiliki aspek kognitif maupun pengaruh. Secara kognitif, yang termasuk dalam keterlibatan adalah pengaruh, seperti evaluasi prodduk. Jika keterlibatan suatu produk tinggi, maka orang akan mengalami tanggapan pengaruh yang lebih kuat, seperti emosi dan perasaan yang kuat. Keterlibatan dapat berkisar dari tingkat yang rendah - sedikit atau tidak ada relevansinya - ketingkat yang moderat-ada relevansi yang dirasakan-hingga ke tingkat yang tinggi-relevansinya sangat dirasakan. Keterlibatan adalah status motivasi yang menggerakkan serta mengarahkan proses kognitif dan perilaku konsumen pada saat mereka membuat keputusan.

4) Dimensi Komunikasi

Dimensi komunikasi memberikan informasi tentang kemampuan konsumen dalam mengingat pesan utama yang disampaikan, pemahaman konsumen, serta kekuatan kesan yang ditinggalkan pesan tersebut. Perspektif pemrosesan kognitif adalah inti untuk mengembangkan strategi pemasaran yang berhasil yang merupakan permasalahan komunikasi.

Proses dimulai ketika sumber komunikasi promosi menentukan informasi apa yang harus dikomunikasikan, kemudian meng-enkoding pesan tersebut dalam bentuk simbol-simbol yang paling tepat (menggunakan kata, gambar, atau tindakan). Kemudian, pesan ditransmisikan ke sebuah penerima melalui berbagai media, seperti pertunjukan televisi, penawaran via pos, billboard, atau majalah. Penerima atau konsumen, jika digiring ke suatu promosi, harus men-dekoding atau menerjemahkan maknanya. Kemudian, konsumen dapat mengambil tindakan, seperti pergi ke toko atau melakukan pembelian. Dua tahapan model komunikasi sangat dibutuhkan, khususnya demi keberhasilan penerapan strategi promosi. Tahapan pertama terjadi ketika pemasar menciptakan komunikasi promosi untuk meng-enkoding suatu makna. Tahap kedua adalah pen-dekoding-an, yaitu konsumen masuk dan memahami informasi dalam komunikasi promosi dan mengembangkan interpretasi pribadi mereka terhadap makna yang ditangkap. 


\section{F. Kerangka Pemikiran}

Untuk memudahkan alur pemikiran dalam penelitian ini, hubungan antar variabel yang terdiri dari empati, persuasi, dampak, dan komunikasi dengan keputusan pembelian akan digambarkan dalam sebuah kerangka pemikiran, sebagai berikut

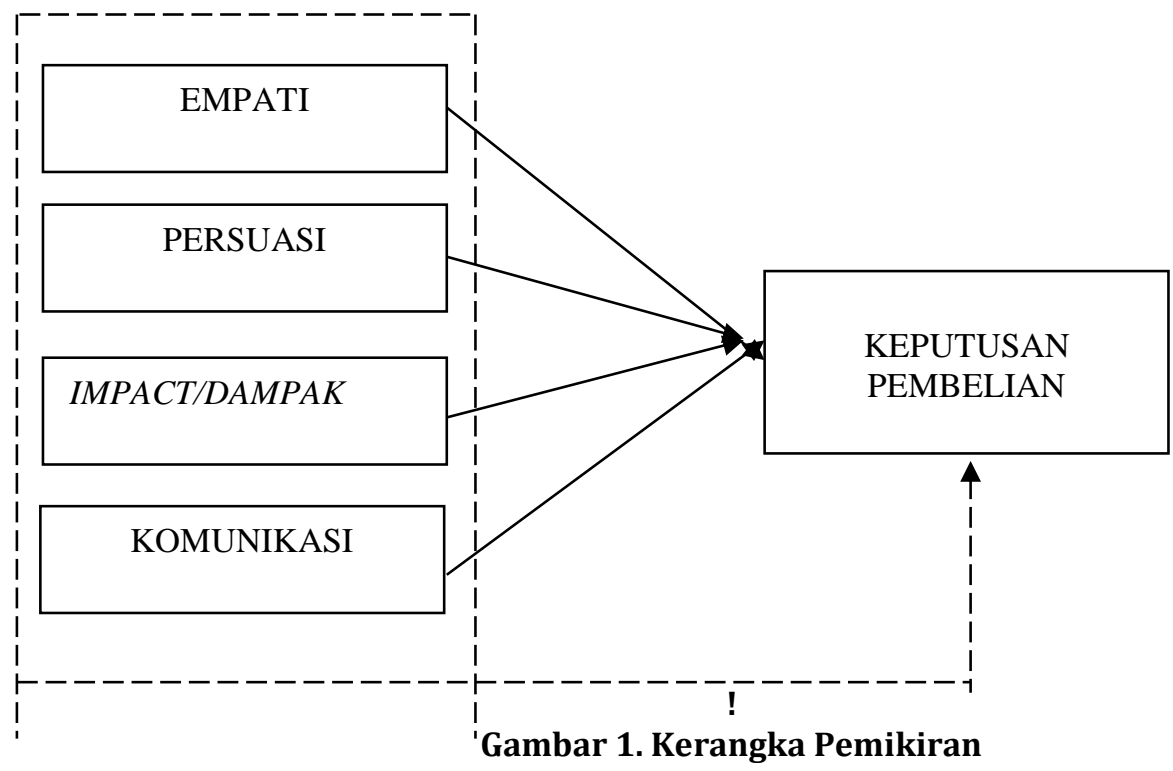

Keterangan :

\section{G. Hipotesis}

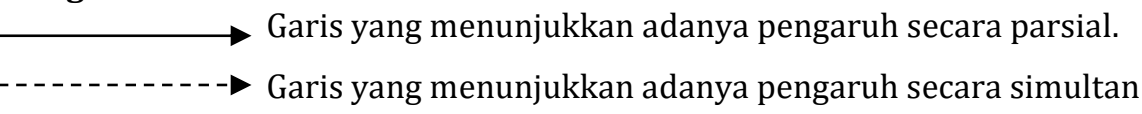

Berdasarkan teori dan hasil penelitian-penelitian yang mendahului, maka dapat dirumuskan suatu hipotesis penelitian sebagai berikut:

1. Diduga terdapat pengaruh positif dan signifikan empathy (empati) terhadap keputusan pembelian konsumen pada Toko Bangunan Radin Timur, di Jebres Surakarta.

2. Diduga terdapat pengaruh positif dan signifikan persuasion (persuasi) terhadap keputusan pembelian konsumen pada Toko Bangunan Radin Timur, di Jebres Surakarta.

3. Diduga terdapat pengaruh positif dan signifikan impact (dampak) terhadap keputusan pembelian konsumen pada Toko Bangunan Radin Timur, di Jebres Surakarta.

.4. Diduga terdapat pengaruh positif dan signifikan communication (komunikasi) di masyarakat terhadap keputusan pembelian konsumen pada Toko Bangunan Radin Timur, di Jebres Surakarta.

5. Diduga terdapat interaksi pengaruh positif secara bersama-sama antara empati, persuasi, dampak, dan komunikasi terhadap keputusan pembelian konsumen pada Toko Bangunan Radin Timur, di Jebres Surakarta.

\section{METODE PENELITIAN}

\section{Ruang Lingkup Penelitian}

Penelitian ini menggunakan desain riset deskriftif untuk menjelaskan efektifitas iklan menggunakan model EPIC terhadap upaya meningkatkan nilai penjualan pada Toko Bangunan Radin Timur, yang berralamat di Jalan. Ir. Sutami No.59B, Pucangsawit, Kecamatan Jebres kota Surakarta.

\section{Populasi, dan Sampel}

Mengingat besarnya populasi dalam penelitian ini kurang dari 100 responden, maka seluruh populasi dalam penelitian ini yang berjumlah 38 orang aktif berbelanja diambil semua untuk 
dijadikan sampel dengan demikian penelitian ini merupakan penelitian sensus. Tehnik pengambilan sampel dengan menggunakan sampling jenuh yaitu semua anggota populasi digunakan sebagai sampel (Sugiyono, 2017: 96).

\section{Teknik Analisis Data}

a. Uji Prasyarat Analisis (asumsi klasik)

b. Analisis Regresi Linier Berganda

Adapun model yang digunakan yaitu:

$\mathrm{Y}_{1}=\mathrm{a}+\mathrm{b}_{1} \mathrm{X}_{1}+\mathrm{b}_{2} \mathrm{X}_{2}+\mathrm{b}_{3} \mathrm{X}_{3}+\mathrm{b} 4 \mathrm{X}_{4}+\mathrm{b}_{5} \mathrm{X}_{5}+\mathrm{b}_{4} \mathrm{X}_{6}+\mathrm{b}_{7} \mathrm{X}_{7}+\mathrm{e}$

\section{HASIL ANALISIS DATA DAN PEMBAHSAN}

a. Uji Instrumen Penelitian

Berdasarkan pada uji instrumen penelitian yang terdiri dari uji validitas dan uji reliabilitas diketahui bahwa tiap item pertanyaan valid dan reliabel memenuhi syarat untuk pengumpulan data

b. Uji Prasyarat Analisis/ Uji asumsi klasik

Telah lolos uji prasyarat analisis oleh karena itu layak untuk memprediksi analisis berikutnya.

c. Uji Regresi Linier Berganda

Hasil uji regresi diperoleh persamaan regresi sebagai berikut :

$$
\mathrm{Y}=1,261+0.297 \mathrm{X}_{1}+0.159 \mathrm{X}_{2}+0.216 \mathrm{X}_{3}+0,293 \mathrm{X}_{4}
$$

d. Uji Hipotesis

1) Uji t (parsial)

Berdasarkan hasil printout menggunakan alat statistik SPSS diperoleh besarnya nilai t seperti pada table di bawah ini.

Berdasarkan pada hasil uji t keempat variabel yaitu variabel empati, variabel persuasi, variabel dampak, variabel komunikasi, diketahui bahwa variabel komunikasi ternyata mempunyai pengaruh yang paling dominan dari pada variabel-variabel lainnya. Hal ini dapat dilihat dari besarnya nilai $\beta$ (beta) masing-masing variabel.

Tabel I.

Hasil Analisis Uji t (t Test)

\begin{tabular}{|c|c|c|c|c|}
\hline \multirow{2}{*}{ Variabel } & \multicolumn{4}{|c|}{ Keterangan } \\
\cline { 2 - 5 } & $\mathrm{SCB}$ & t_hitung & Sig. & Keterangan \\
\hline $\mathrm{X}_{1}$ & 0,329 & 3.202 & 0.003 & $\mathrm{H}_{0}$ ditolak \\
\hline $\mathrm{X}_{2}$ & 0,89 & 2.190 & 0.036 & $\mathrm{H}_{0}$ ditolak \\
\hline $\mathrm{X} 3$ & 0,209 & 2.232 & 0.033 & $\mathrm{H}_{0}$ ditolak \\
\hline $\mathrm{X} 4$ & 0,319 & 2.919 & 0.006 & $\mathrm{H}_{0}$ ditolak \\
\hline
\end{tabular}

Sumber : Olahan SPSS th 2020..

Keterangan : ${ }^{*} p<0,05,{ }^{* *} p<0,01$ 
2) Uji F

Uji F (Fisher) adalah digunakan untuk menunjukkan apakah sekelompok variabel bebas secara bersama-sama mempunyai pengaruh terhadap variabel terikat. Berdasarkan hasil printout menggunakan alat statistik SPSS diperoleh besarnya nilai t seperti pada table di bawah ini.

Tabel 2.

Hasil Analisis Uji F (F Test)

\begin{tabular}{|c|c|c|l|}
\hline Fhitung & Ftabel $_{\text {tan }}$ & Signifikansi & Kesimpulan \\
\hline 77,235 & 2,21 & 0,000 & Ho ditolak \\
\hline
\end{tabular}

Sumber: Olahan SPSS th 2020.

3) Koefisien Determinasi

Besarnya koefisien determinasi adalah 0,892 yang berarti bahwa sumbangan pengaruh dari variabel empati, persuasi, dampak, dan komunikasi terhadap keputusan pembelian sebesar $89,20 \%$, sedangkan sisanya yaitu $10,80 \%(100 \%-89,20 \%)$ berasal dari pengaruh faktorfaktor lain diluar penelitian ini.

\section{HASIL PENELEITIAN}

Hasil penelitian diperoleh:

1. Bahwa variabel empati, mempunyai pengaruh terhadap keputusan pembelian bahan bangunan di toko bangunanan Radin Timur Jebres Surakrta. Hal ini dapat ditunjukkan dari besarnya koefisien regresi yang bertanda positif untuk empati yaitu 0,297. Dengan sig.0,003 < 1\%.

2. Bahwa variabel persuasi mempunyai pengaruh terhadap terhadap keputusan pembelian bahan bangunan di toko bangunanan Radin Timur Jebres Surakrta.. Hal ini dapat ditunjukkan dari besarnya koefisien regresi yang bertanda positif Untuk persuasi sebesar 0,159. Dengan sig.0,036 $<5 \%$.

3. Bahwa variabel dampak mempunyai pengaruh terhadap terhadap keputusan pembelian bahan bangunan di toko bangunanan Radin Timur Jebres Surakrta.. Hal ini dapat ditunjukkan dari besarnya koefisien regresi yang bertanda positif untuk dampak iklan sebesar 0,216. Dengan sig. $0,033<5 \%$.

4. Bahwa variabel komunikasi mempunyai pengaruh terhadap keputusan pembelian bahan bangunan di toko bangunanan Radin Timur Jebres Surakrta. Hal ini dapat ditunjukkan dari besarnya koefisien regresi yang bertanda positif komunikasi sebesar 0,293. Dengan sig.0,006 < $1 \%$.

1. Faktor Empati paling domain pengaruhnya terhadap keputusan pembelian bahan bangunan di toko bangunanan Radin Timur Jebres Surakrta.. Hal ini dapat ditunjukkan oleh besarnya SC betanya yaitu sebesar 0,329.

2. Apabila dilihat dari besarnya angka koefisien determinasi adalah 0,892 yang berarti bahwa sumbangan pengaruh dari variabel empati, persuasi, dampak, dan komunikasi, terhadap Keputusan Pembelian sebesar $89,20 \%$, sedangkan sisanya yaitu $10.80 \%$ berasal dari pengaruh faktor-faktor lain di luar penelitian ini.

\section{DAFTAR PUSTAKA}

Aaker, A., Kumar V. And Day G.S., (2011). Marketing Research, Seventh Edition, New York: John Wiley \& Sons, Inc.

Anonim, (2016) Kamus Besar Bahasa Indonesia (KBBI). Edisi Kelima. Jakarta: Balai Pustaka, Departemen Pendidikan Nasional 
Durianto, D. Sugiarto, A, W, Widajaj, Hendrawan, S., (2017). Invasi Pasar Dengan Iklan Yang Efektif, Jakarta: PT. Gramedia Pustaka Utama.

Dian B., dan Edy W., (2017) Analisis Perbandingan Efektivitas Iklan Menggunakan EPIC Model Terhadap Mahasiswa UII Yogyakarta. Prosiding SI MaNIs (Seminar Nasional Integrasi Matematika dan Nilai Islami) Vol.1, No.1, Juli 2017, Hal. 214-220

Dewi R. I. dan Zenitha M., (2017) meneliti tentang: Analisis Efektifitas Iklan Media Televisi Menggunakan EPIC Model (Studi Kasus Produk A Mild di Kota Langsa). Jurnal Penelitian Ekonomi Akuntansi (Jensi), Vol. 1, No. 2, Desember.

Hakim, A., (2018). Statistik Induktif, untuk Ekonomi dan Bisnis, Edisi Pertama, Cetakan Pertama, Yogyakarta : Ekonisia.

Jhon, C., (2013). Tested Advertising Methods . fifth edition, New York: Prentice Hall.

Kotler, P., 2008. Manajemen Pemasaran, Analisis, Perencanaan dan Pengendalian, Edisi Kelima, Cetakan Ketiga, diIndonesiakan Oleh Herujati Purwoko, Jakarta : Penerbit Erlangga.

Tjiptono, F., (2014). Strategi Pemasaran, Cetakan Pertama, Yogyakarta Edisi Kedua Penerbit Andi..

Rangkuti, F., (2017), Riset Pemasaran Penerbit, Jakarta: PT.Gramedia.

Gesty E., dan , Subagyo (2020). Dalam penelitian yang berjudul: Media Promosi Produk UMKM dengan Menggunakan EPIC Model. Efektor, Volume, 7, Issue 1, 2020, Pages 1 - 14.

Ghozali, I. (2018), Aplikasi Analisis Multivariate dengan program SPSS 25, Semarang: Badan. Penerbit Universitas Diponegoro.

Ika B. S. dan Kristian S. W. N., (2019), dalam penelitiannya ang berjudul: Epic Model: Efektivitas Iklan Destinasi Wisata Kabupaten Banyuwangi Terhadap Minat Berkunjung Ulang Wisatawan Domestik. Management Insight, 13 (2): 8-26.

J. Supranto, 2011. Metode Penelitian, Yogyakarta: Penerbit Unit Penerbit dan Percetakan (UPP) Akademi Manajemen Perusahaan YKPN.

Peter, J. P., and Olson J. C., (2016). Consumer Behavior and Marketing Strategy. 4th ed. The McGraw Hill Companies, Inc.

Peter D. dan A. Fansusu, (2016). strategic marketing communication. Jakarta: PT. Gramedia Pustaka Utama.

Swastha, B. DH dan Irawan, 2011. Manajemen Pemasaran Modern, Edisi Kedua, Cetakan Kesebelas, Yogyakarta : Penerbit Liberty.

Swastha, B. DH., 2013. Asas-asas Marketing, Edisi Ketiga, Yogyakarta : Penerbit Liberty.

Widya Sastika (2018) yang berjudul : Epic Model: Pengukuran Efektivitas Iklan Kuliner Melalui Sosial Media Instagram @Kulinerbandung Sebagai Media Promosi. Jurnal Teknologi Informasi dan Manajemen Edisi 1, Volume 1, Bulan Juli, Tahun 2018. E-ISSN 2622-2647

Sekaran, Uma. (2016). Research methods for business. A skill building approach, (3rd ed.) New York: Wiley

Sofjan Assauri, (2017) Manajemen Pemasaran, Jakarta: Rajawali Pers,

Sugiyono, (2014). Metode Penelitian Bisnis Pendekatan Kuantitatif \& Kualitatif R\&D, Bandung: Alfabeta. 
Sulaksana, Uyung. (2014). Integrated Marketing Communications Teks dan Kasus. Yogyakarta: Pustaka Pelajar

Teguh Budiarto dan Fandy Ciptono. (2014). Pemasaran Internasional. Edisi Pertama. Yogyakarta: BPFE-UGM.

Thoyibie, Lafif. (2019). Peranan Public Relations. Http//:Komunikasi.Indonesia. Org/ Peranan Public Relations.

Tunggal,Amin Wijaya (2019), Manajemen Kontenporer, Buku 2, Jakarta: Harvarindo

Wenny Kartika Susanto dan Keni (2018). Pengaruh Social Network Marketing (SNM) Dan Electronic Word Of Mouth (Ewom) Terhadap Minat Beli Pelanggan. Jurnal Manajemen Bisnis Dan Kewirausahaan/ Volume 02/No.6/ November-2018:68-73

Yuliansyah, 2019. Meningkatkan Respon Rate pada Penelitian Survey. Suatu Studi Literatur. Jakarta: Smart, Imprint Change Publication. 